\title{
ULTRASTRUCTURAL MODIFICATIONS IN LICHENS INDUCED BY ENVIRONMENTAL HUMIDITY
}

\author{
C. ASCASO ${ }^{\star}$
}

\section{Introduction}

Ultrastructural studies of lichens have not paralleled investigations on lichen physiology and, with one exception (Harris and Kershaw, 1971), morphological changes have not been studied under controlled environmental conditions. Moreover, contradictory results on the same topic have been published. For example, Brown and Wilson (1968) and Jacobs and Ahmadjian (1971a) claimed that under damp conditions lichen thalli frequently contained starch inclusions, whereas other results (Harris and Kershaw, 1971; Ascaso and Galván, 1976) conflicted with this observation. According to Webber and Webber (1970), starch granules do not appear in wet thalli collected in the spring because of the increased metabolic requirement of the mycobiont.

The pyrenoid of green phycobionts usually contains a variable amount of electron-dense particles named pyrenoglobuli; these seem to be lipid in nature and are considered as secondary storage products (Jacobs and Ahmadjian, 1969, $1971 a, b)$. Jacobs and Ahmadjian (1973) pointed out that the behaviour of pyrenoglobuli under different environmental conditions remained obscure. Dampness seemed to increase the number of globuli (Rudolph and Giesy, 1966; Peveling, 1969) except in one case (Brown and Wilson, 1968), and short-term desiccation was found to reduce their amount (Peveling, 1968) without detectable damage to the thylakoids. Other ultrastructural changes of the phycobiont that occur under dry conditions have been reported by Peveling and Galun (1976).

The above reports have all failed to take into account several ecological factors (e.g. moisture, temperature) and thus a meaningful comparison of these results is not possible. In long-term experiments we have shown that, under controlled experimental conditions, dryness causes a large number of ultrastructural modifications in both the phycobiont and the mycobiont (Ascaso and Galván, 1976). The variations in the amounts of pyrenoglobuli and starch seem to be correlated with changes in the physiology of the algal component (Ahmadjian, 1974); such changes are likely to be induced by alterations in the ecological conditions.

On the other hand, physiological studies on both the photosynthesis and respiration of lichens (Feige, 1972; Richardson, 1973; Larson and Kershaw, 1975; Kallio and Kärenlampi, 1975) and the nutrient movement between symbionts (Richardson et al., 1967; Richardson, 1973; Armstrong, 1976; Hill, 1976) have not been complemented by ultrastructural investigations.

The aim of the present work was to study, by electron microscopy, the response of three lichens to moderately dry and wet conditions. The moisture levels were selected so as to correspond to those for which physiological data are available.

* Instituto de Edafología y Biología Vegetal, Serrano, 115 bis, Madrid 6, Spain. 


\section{Materials and Methods}

The lichens used, Parmelia tiliacea s.s., Lasallia pustulata and Ramalina protecta, were all collected from Las Cancheras, Madrid, Spain $\left(41^{\circ} 11^{\prime} 25^{\prime \prime} \mathrm{N}, 0^{\circ} 11^{\prime} 40^{\prime \prime} \mathrm{E}\right)$. All have Trebouxia as phycobiont. The specimens were collected in the summer and the rainfall and temperatures before sampling are shown in Fig. 1.
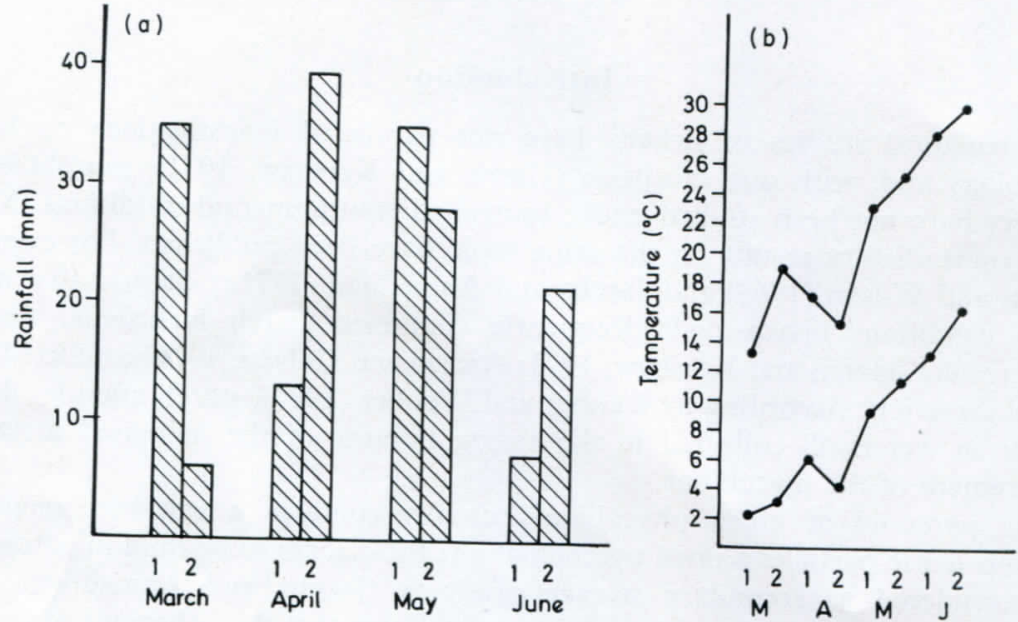

FIG. 1. (a) Rainfall measured in the field before sampling. (b) Maximum and minimum average temperatures measured every 15 days.

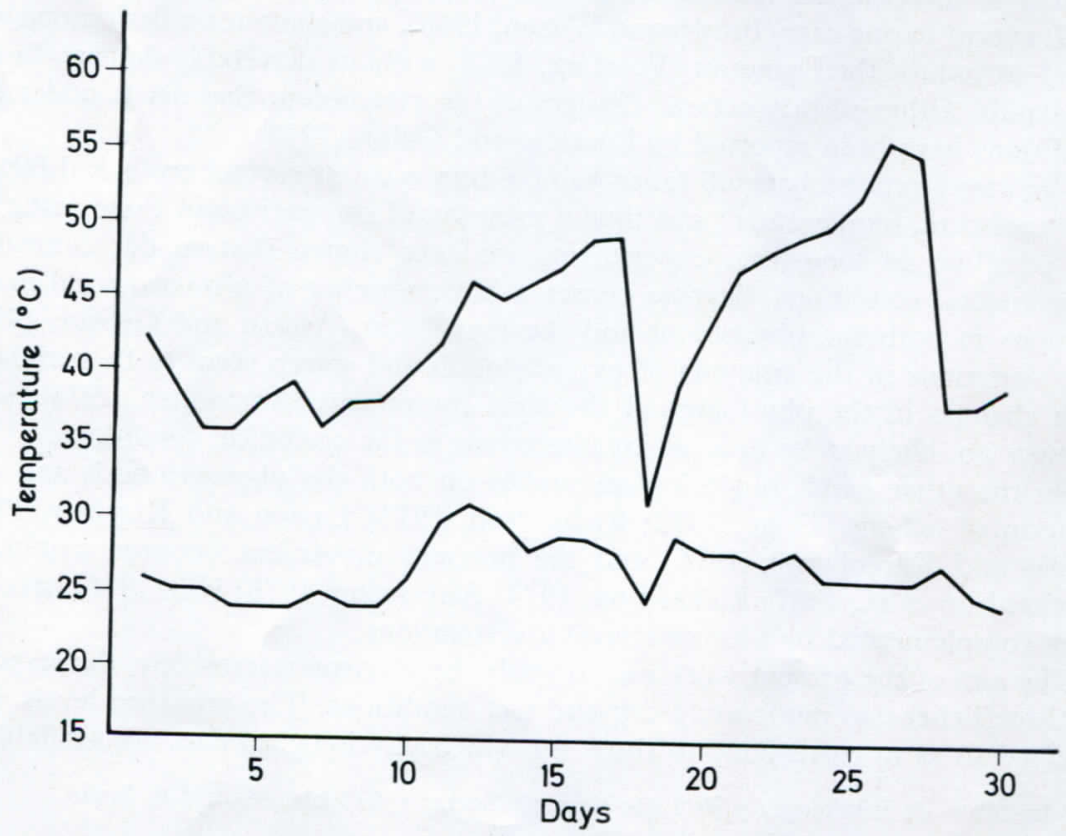

FIG. 2. Maximum and minimum temperatures measured in all the boxes. 
Part of the material was immediately processed for electron microscopy as described by Ascaso and Galván (1976). Other samples containing the lichens on their original rock substrates were subjected to three different experimental conditions: (a) control samples, without any special moisture treatment; (b) dry-treated samples by the presence of indicatorcontaining silica gel (the silica gel was changed every 3 days before any change in the indicator colour occurred); and (c) wet-treated samples in which the lichens were retained in a continuously moistened atmosphere (using water-impregnated filter paper). Each category of

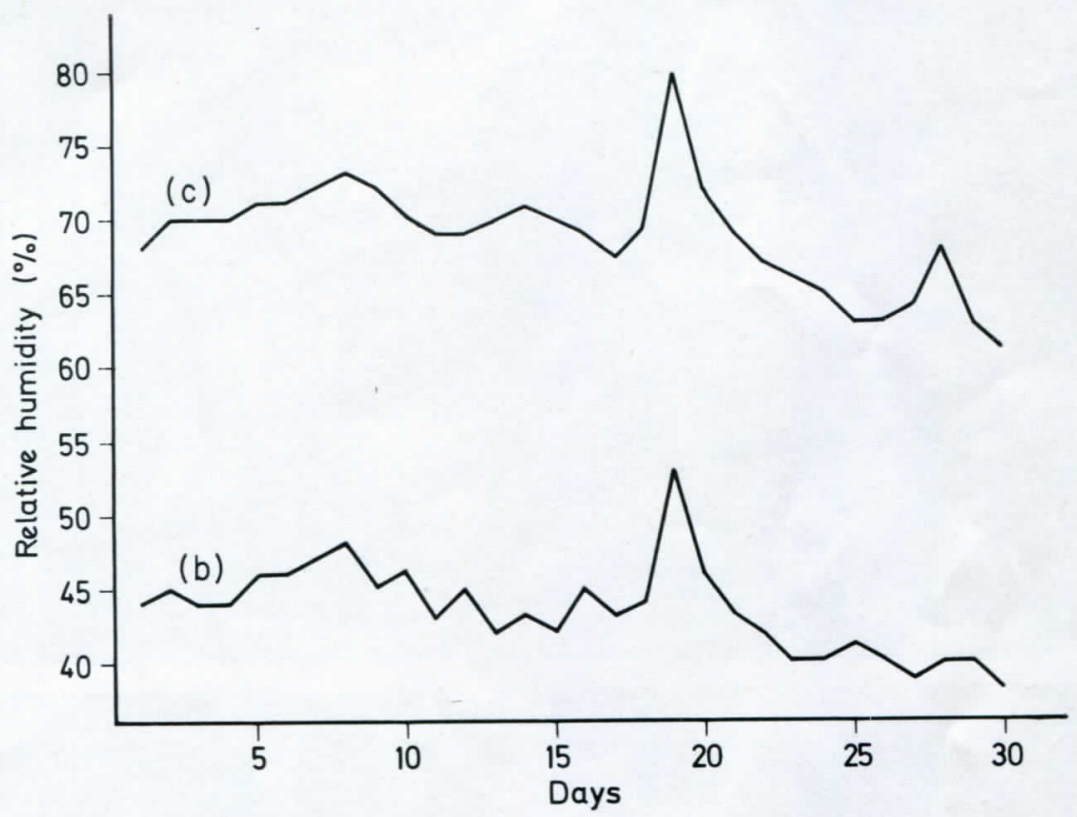

FIG. 3. Relative humidity (\%) in the boxes containing: (b) $40-60 \%$ relative humidity treated samples and (c) $60-80 \%$ relative humidity treated samples.

samples was subjected to the above conditions for 30 days in polystyrene boxes provided with a glass window to permit their illumination. Air was supplied to the boxes through a cotton wool filter. Maximum and minimum temperatures are shown in Fig. 2, while Fig. 3 shows variations in the relative humidity in treatments (b) and (c). Control values were intermediate between (b) and (c) values. The light period in the greenhouse was about $14 \mathrm{~h} /$ day. The highest intensity of light reached at noon was about $30 \mathrm{klx}$. After 30 days, the samples were also processed for electron microscopy as noted above.

\section{Results}

The algal-symbiont of $P$. tiliacea (field samples) showed a typical distribution of the thylakoids in the chloroplast but an irregularly covered pyrenoid (Fig. 4). Mitochondria were frequently seen in the upper cortical hyphae and dark storage bodies occurred in the medullary hyphae (Fig. 5). Woronin bodies (Reichle and Alexander, 1965) were present in the majority of the contacts between hyphae. Concentric bodies were also found.

The pyrenoid lacked a definite internal structure and the pyrenoglobuli had a peripheral distribution; these were associated with the scarce thylakoids that 

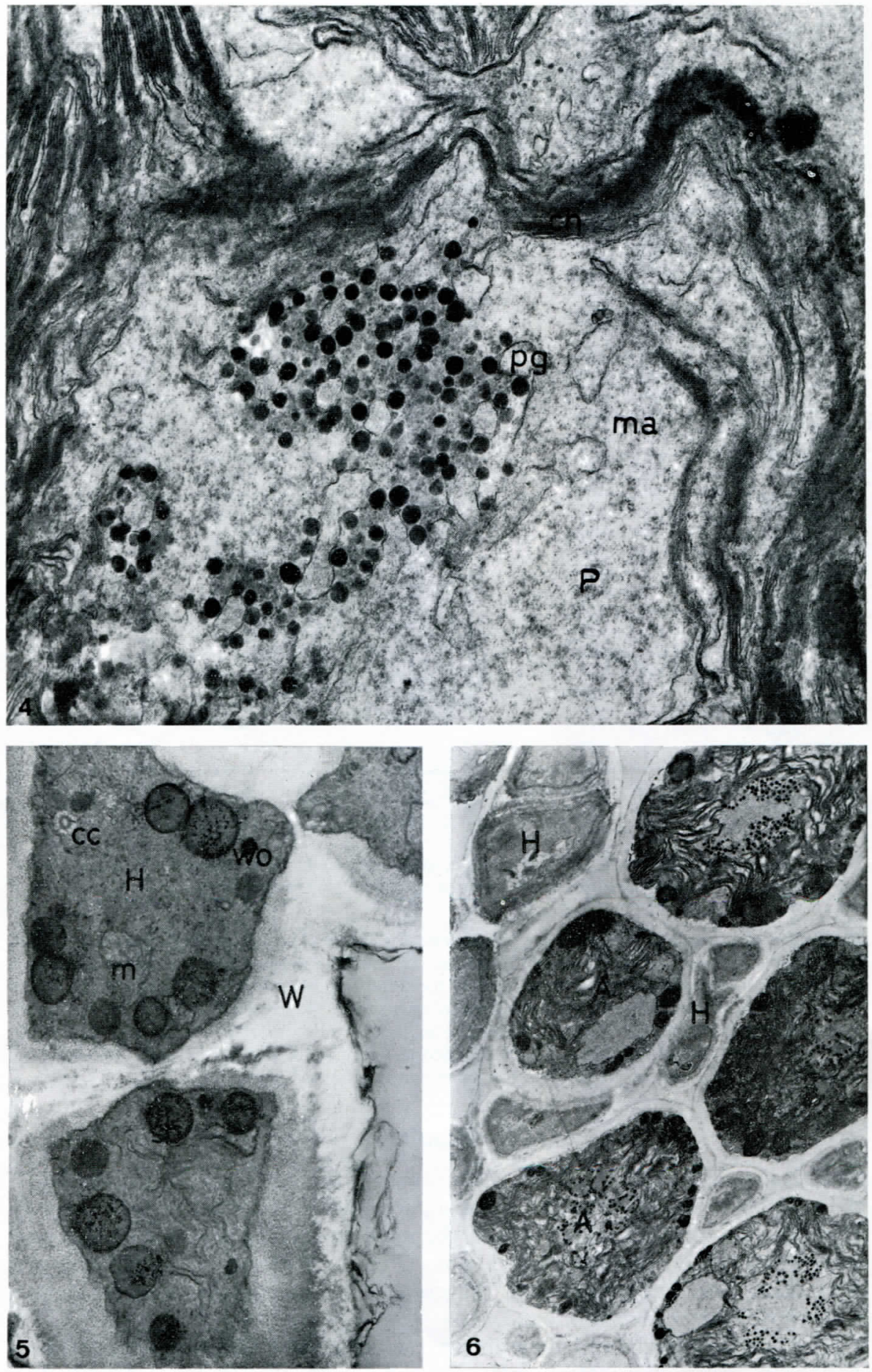

FIG. 4. Parmelia tiliacea. Field sample. Algae. A near median section through a pyrenoid. ch, chloroplast; P, pyrenoid; pg, pyrenoglobulus; ma, matrix. $\times 33,500$.

FIG. 5. Parmelia tiliacea. Field sample. Section through the medullary layer. $\mathrm{H}$, hypha; W, cell wall; m, mitochondrion; sb, storage body; Wo, Woronin body; cc, concentric body. $\times 24,300$.

FIG. 6. Parmelia tiliacea. Relative humidity treatment, 40-60\%. Aspect of the algal layer. A, alga; H, hypha. $\times 5000$. 

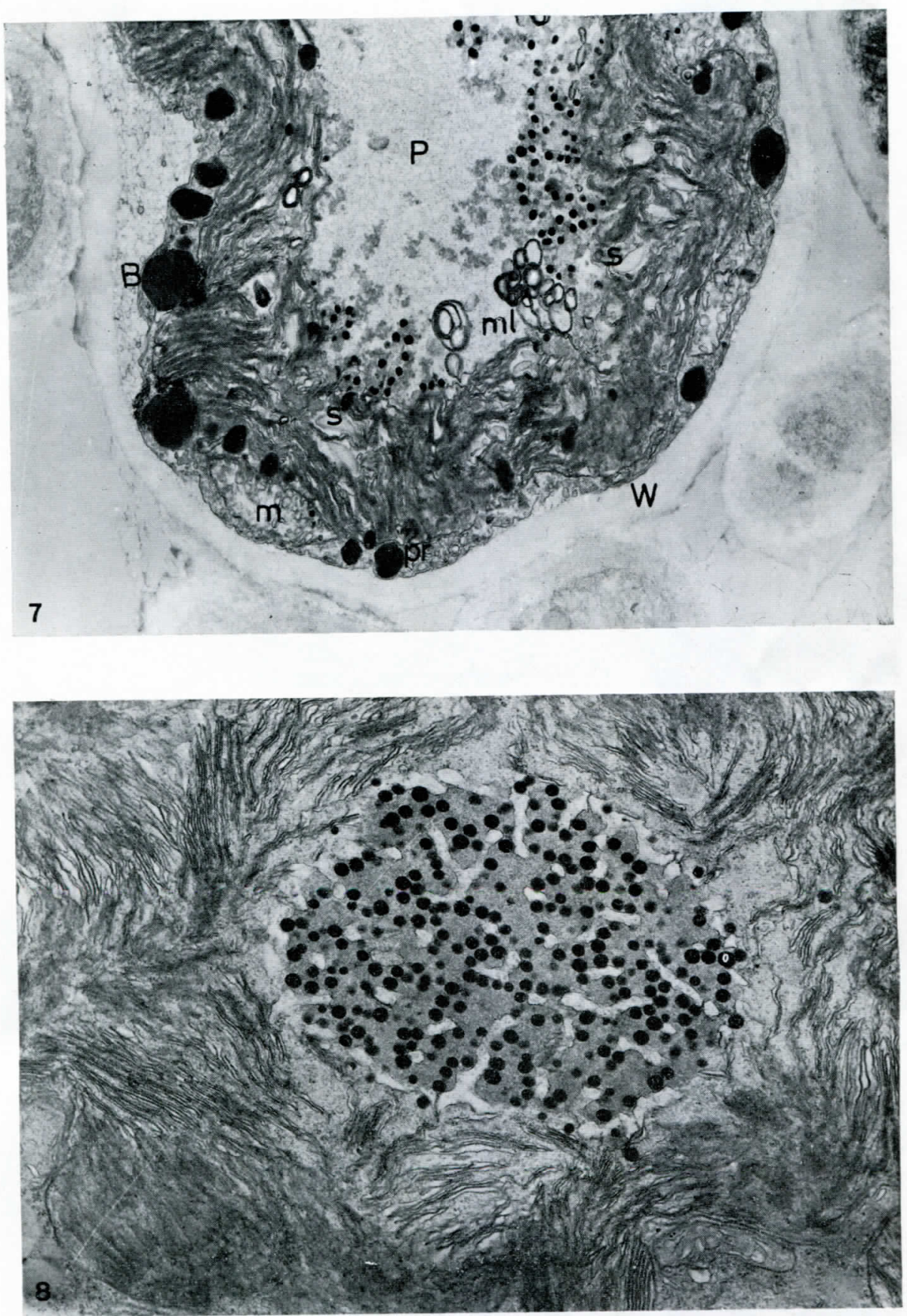

FIg. 7. Parmelia tiliacea. Relative humidity treatment, 40-60\%. Alga. W, cell wall; pr, protoplasm; P, pyrenoid; s, starch; B, dark and polygonal body; ml, multilamellate or myelin-like body; $\mathrm{m}$, mitochondrion. $\times 16,500$.

FIG. 8. Parmelia tiliacea. Relative humidity treatment, $60-80 \%$. Alga. $\times 19,000$. 

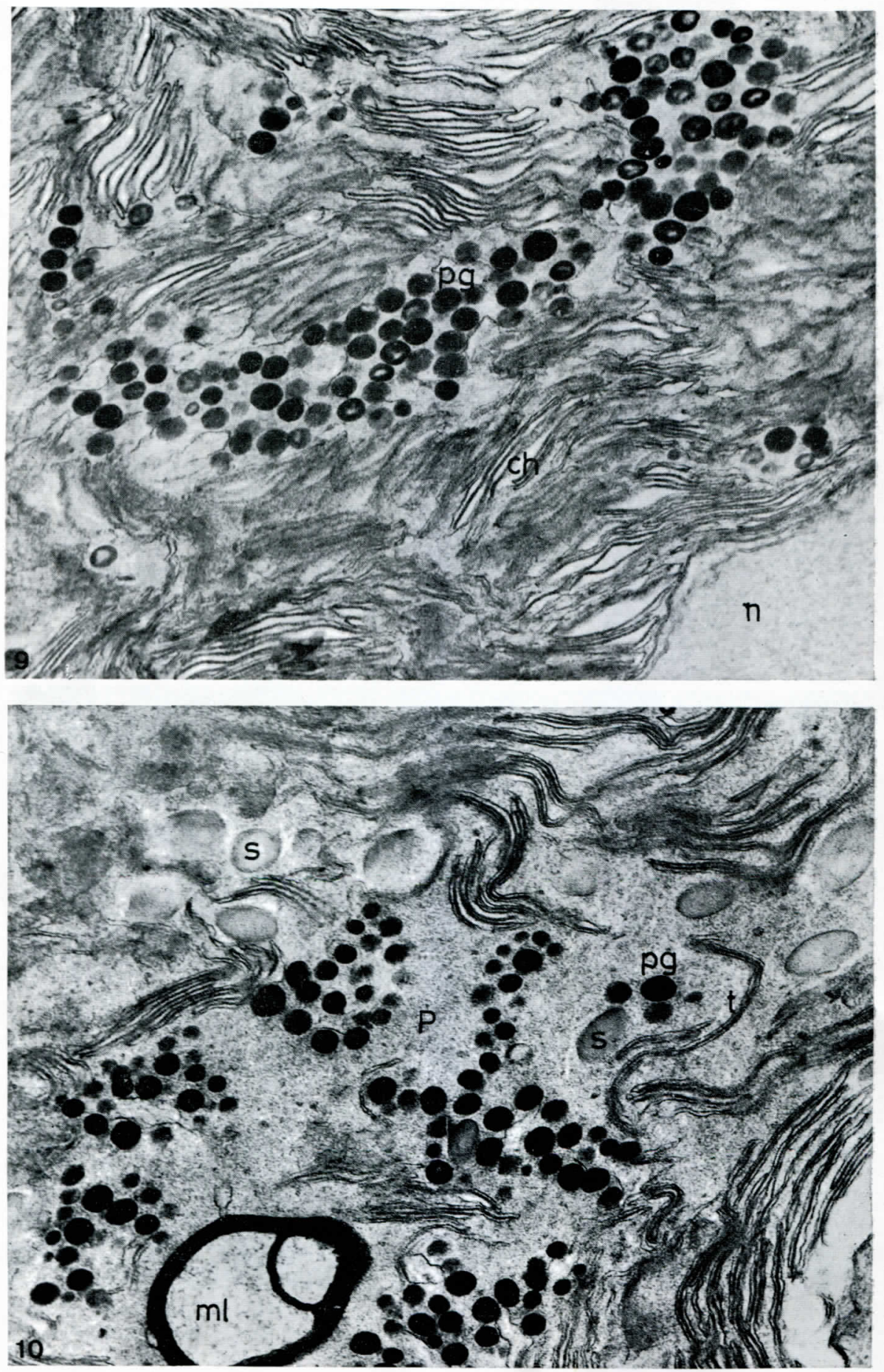

FIG. 9. Lasallia pustulata. Field sample. Alga. ch, chloroplast; pg, pyrenoglobulus; n, nucleus. $\times 51,000$.

FIG. 10. Lasallia pustulata. Relative humidity treatment, 40-60\%. Section through the central part of the chloroplast. P, pyrenoid; t, thylakoid; ml, multilamellate body; pg, pyrenoglobulus; s, starch. $\times 39,000$. 

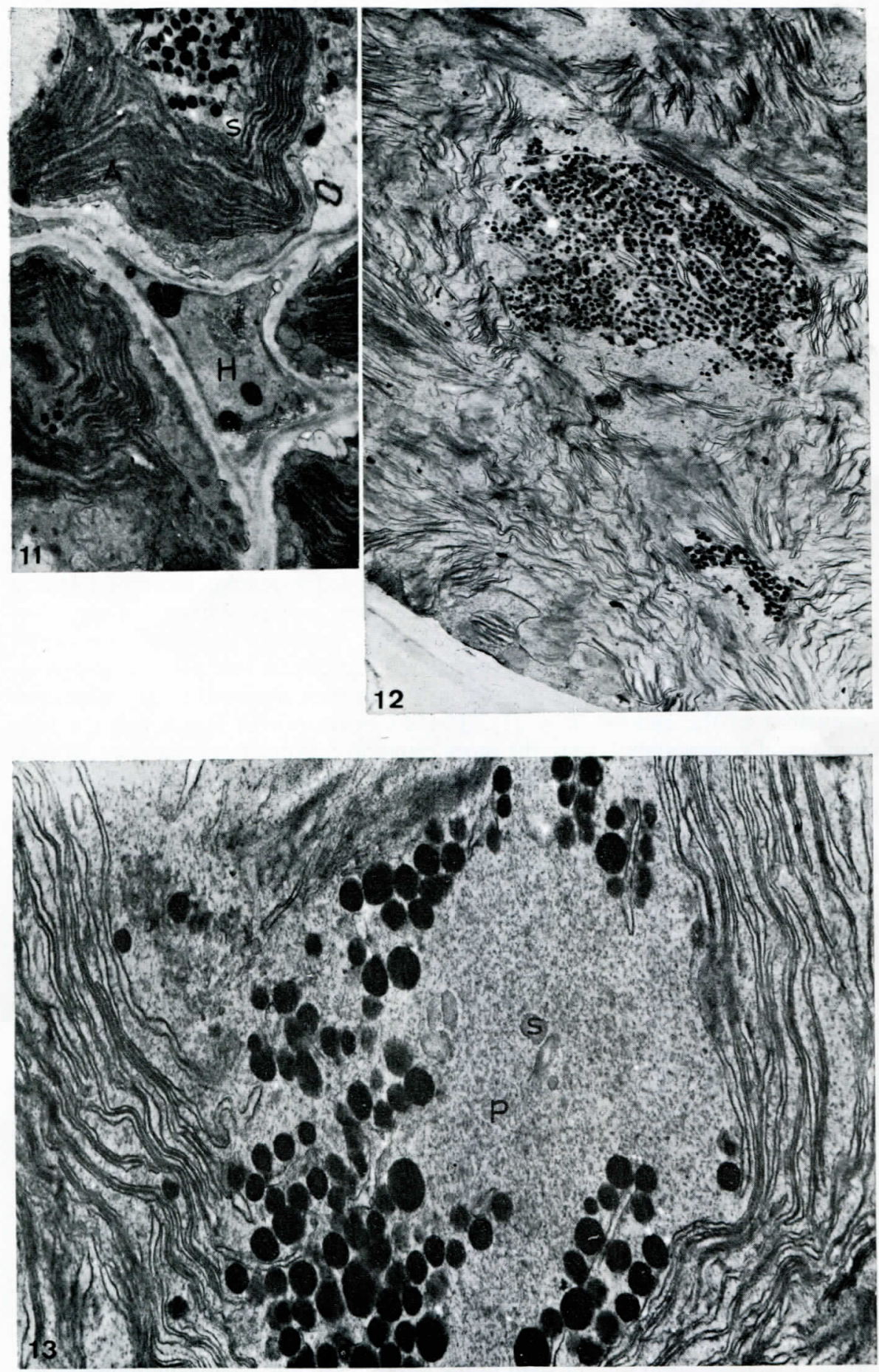

FIG. 11. Lasallia pustulata. Control sample. Algal layer. A, alga; H, hypha; s, starch. $\times 19,000$. FIG. 12. Ramalina protecta. Control sample. Pyrenoid and a part of the chloroplast. $\times 9000$. FIG. 13. Ramalina protecta. Relative humidity treatment, $40-60 \%$. P, pyrenoid; s, starch. $\times 47,000$. 
remained in the pyrenoid in the control treatment but more pronounced in the samples subjected to low humidity (Figs 6-7). Starch granules were found to be very frequent between the thylakoids around the pyrenoids (Figs 6-7) but were not observed in field samples of $P$. tiliacea. Beside the plasmalemma, numerous dark and polygonal storage bodies occurred. The mitochondria seemed to have a swollen morphology.

When $P$. tiliacea was subjected to wet conditions, the algal cells contained a pyrenoid very densely covered with numerous pyrenoglobuli (Fig. 8). Very electrondense storage granules were seen associated with the plasmalemma in $80 \%$ of the cells and, in the remainder of the cells, these granules were almost greyish and round in shape. No starch was found in these samples. The mycobiont did not show any appreciable alterations in ultrastructure. Furthermore, the fungus-alga association remained unaltered and only wall-wall contacts were observed.

In samples of $L$. pustulata fixed immediately after collection many of the algal cells had a branched pyrenoid which contributes to the location of the pyrenoglobuli at unusual positions in the chloroplast (Fig. 9). In the phycobionts subjected to other treatments the more common organelles were demonstrable in the cells and a certain number of bodies intermediate in electron density occurred at their periphery. Vesicular bodies are also frequently seen in this region of the cell. After the dryness treatment, however, no branched pyrenoids could be found in $80-85 \%$ of the algal cells. The pyrenoglobuli were now peripheral and very close to the starch granules. Multilamellate bodies, probably resulting from coiled thylakoids, were also found in the pyrenoid (Fig. 10). A low number of pyrenoglobuli and an increase in the amount of starch were observed in dry samples as compared to the control (Fig. 11). The disappearance of starch and the large number of pyrenoglobuli were the more common features in wet samples. Wall to wall contacts and a typical ultrastructure of the fungus were observed in all the specimens.

Field samples of Ramalina protecta contained a large number of pyrenoglobuli in an oval pyrenoid; branched pyrenoids were only observed occasionally. Control samples exhibited some clear zones in the pyrenoid (Fig. 12) but no starch was observed. In the dry environment, a severe reduction in the number of pyrenoglobuli occurred and these were almost all peripheral; starch inclusions were also detected in the pyrenoid in these samples (Fig. 13). Wet samples, in common with the controls, did not contain starch granules. In $50 \%$ of these samples, the number of pyrenoglobuli per pyrenoid was intermediate between that of the controls and that of the dry samples. The remaining algae showed higher amounts of these globuli. Only wall to wall contacts were observed between the bionts.

\section{Discussion}

The rationale of this work was supported by several well-documented results. First, that mature saxicolous lichens are almost independent of their substrate with respect to water uptake (Scott, 1964); water is mostly incorporated into the thallus from the atmosphere. Secondly, the absorption of water vapour is a very slow process that takes a long time to reach equilibrium (Ried, 1960a); for this reason a 30 day experimental period was deemed appropriate. Thirdly, since the water level in the thallus is always lower than in the atmosphere, the relative humidity values 
in the boxes were slightly higher than the optimal water contents of lichens (Kershaw, 1972).

The results presented above allow several conclusions to be drawn. In the dryness-treated samples, the numbers of pyrenoglobuli were severely reduced in the centre of the pyrenoid leading to a peripheral distribution of these bodies. These findings are in agreement with those reported previously by Peveling (1968), Jacobs and Ahmadjian (1973) and ourselves (Ascaso and Galván, 1976). One explanation for this phenomenon is that the lipid components of pyrenoglobuli are respired providing both water and carbon to the lichen (Jacobs and Ahmadjian, 1973). However, the disappearance of pyrenoglobuli could also be a consequence of the observed alteration of the pyrenoid matrix as has previously been suggested (Ascaso and Galván, 1976). At this moment, it is not possible to rule out either of these possibilities.

According to Lange (1953, 1969), photosynthesis can take place efficiently at high temperatures in samples subjected to low environmental humidity. In our experiments, daylight temperatures ranged between 30 and $50^{\circ} \mathrm{C}$. However, in these conditions of low humidity the fungal metabolic activity is inhibited as was shown by Harris and Kershaw (1971). For these reasons, in the boxes subjected to low humidity conditions the net photosynthesis should be high. During the night, the lowest temperatures were close to the optimum for the respiration of the lichen thallus (Ahmadjian, 1967); however, the environmental dryness in these samples was harmful for the respiratory process as was shown by Ried $(1960 a, b)$. As a consequence of these phenomena, the net photosynthesis is high and this leads to an accumulation of storage products (starch) in the algal chloroplast. Furthermore, the photosynthetic production could not be matched by transfer which can depend on the fungal metabolism or the presence of a water film between the bionts. The accumulation of carbohydrate in the alga confirms the results of Ascaso and Galván (1976) in L. pustulata and two further species subjected to long dry periods, as well as those of Harris and Kershaw (1971) in two Parmelia species.

Starch grains were not observed in the samples subjected to damp conditions. This might be due to an impairment of the photosynthesis produced by the elevated temperatures in a damp environment ( $60-80 \%$ relative humidity) (Kallio and Kärenlampi, 1975); such an impairment might limit the respiratory activity of the fungus. Both the temperature and humidity will be optimal for respiration in the dark and, for this reason, all the carbohydrates synthesized in the light would be re-utilized and will rapidly turn over. These results are in contrast to those reported by Brown and Wilson (1968) and Jacobs and Ahmadjian (1971a). Further morphological and physiological studies are in progress in order to reach a better understanding of the ultrastructural modifications induced by ecological factors in lichens.

Finally, our results confirm the appearance of electron-dense inclusions in the algal cells under dry conditions as reported previously in L. pustulata (Ascaso and Galván, 1976) and Coccomyxa (Peveling and Galun, 1976).

\section{Summary}

Ultrastructural modifications of Parmelia tiliacea, Lasallia pustulata and Ramalina protecta grown under different degrees of humidity have been investigated. It was 
found that: (a) at a relative humidity of $40-60 \%$ the pyrenoid matrix was partially disorganized, that the number of pyrenoglobuli became drastically reduced, their position was peripheral, and starch storage granules were always numerous; (b) at a relative humidity of $60-80 \%$ the number of pyrenoglobuli increased and starch inclusions were absent. No changes were detected in the mycobiont. These results are discussed in relation to the physiological behaviour of lichens under the conditions employed.

I wish to express my gratitude to Dr J. Galván for his encouragement and to Mr F. Pinto for his skilful technical assistance.

\section{REFERENCES}

Ahmadjian, V. (1967) The Lichen Symbiosis. Waltham, Mass: Blaisdell.

Ahmadjian, V. (1974) ['1973'] Resynthesis of lichens. In The Lichens (V. Ahmadjian and M. E. Hale, eds): 565-579. New York and London: Academic Press.

Armstrong, R. A. (1976) The influence of the frequency of wetting and drying on the radial growth of three saxicolous lichens in the field. New Phytol. 77: 719-724.

Ascaso, C. and Galván, J. (1976). The ultrastructure of the symbionts of Rhizocarpon geographicum, Parmelia conspersa and Umbilicaria pustulata growing under dryness conditions. Protoplasma 87: 409-418.

Brown, R. M. and Wilson, R. (1968) Electron microscopy of the lichen Physcia aipolia (Ehrh.) Nyl. F. Phycol. 4: 230-240.

Feige, G. B. (1972) Ecophysiological aspects of carbohydrate metabolism in the marine blue green algal lichen Lichina pygmaea Ag. Z. Pflanzenphysiol. 68: 121-126.

Harris, G. P. and Kershaw, K. A. (1971) Thallus growth and the distribution of stored metabolites in the phycobionts of the lichens Parmelia sulcata and P. physodes. Can. $\mathcal{F}$. Bot. 49: 1367-1372.

Hill, D. J. (1976) The physiology of lichen symbiosis. In Lichenology: Progress and Problems (D. H. Brown, D. L. Hawksworth and R. H. Bailey, eds): 457-496. London, New York and San Francisco: Academic Press.

Jacobs, J. B. and Ahmadjian, V. (1969) The ultrastructure of lichens. I. A general survey. F. Phycol. 5: 227-240.

Jacobs, J. B. and Ahmadjian, V. (1971a) The ultrastructure of lichens. II. Cladonia cristatella: the lichen and its isolated symbionts. F. Phycol. 7: 71-82.

Jacobs, J. B. and Ahmadjian, V. (1971b) The ultrastructure of lichens. IV. Movement of carbon products from alga to fungus as demonstrated by high resolution radioautography. New Phytol. 70: 45-50.

Jacobs, J. B. and Ahmadjian, V. (1973) The ultrastructure of lichens. V. Hydrothyria venosa, a freshwater lichen. New Phytol. 72: 155-160.

Kallio, P. and Kärenlampi, L. (1975) Photosynthesis in mosses and lichens. In Photosynthesis and Productivity in Different Environments [International Biological Programme, Vol. 3] (J. P. Cooper, ed.): 393-423. London: Cambridge University Press.

Kershaw, K. A. (1972) The relationship between moisture content and net assimilation rate of lichen thalli and its ecological significance. Can. F. Bot. 50: 543-555.

Lange, O. L. (1953) Hitze und Trockenresistenz der Flechten in Bezeihung zu ihrer Verbreitung. Flora, fena 140: 39-97.

Lange, O. L. (1969) Experimentell-ökologische Untersuchungen an Flechten der NegevWuste. I. $\mathrm{CO}_{2}$ Gaswechsel von Ramalina maciformis (Del.) Bory unter kontrollierten Bedingungen im Laboratorium. Flora, fena 158: 324-359.

Larson, D. W. and Kershaw, K. A. (1975) Measurement of $\mathrm{CO}_{2}$ exchange in lichens: a new method. Can. F. Bot. 53: 1535-1541.

Peveling, E. (1968) Elektronenoptische Untersuchungen an Flechten. I. Strukturveränderungen der Algenzellen von Lecanora muralis (Schreb. Rabenh. (= Placodium saxicolum (Nyl.) sec. Klem.) beim Eindringen von Pilzhyphen. Z. Pflanzenphysiol. 59: $172-183$. 
Peveling, E. (1969) Elektronenoptische Untersuchungen an Flechten. II. Die Feinstruktur von Trebouxia-phycobionten. Planta, Berl. 87: 69-85.

Peveling, E. and Galun, M. (1976) Electron-microscopical studies on the phycobiont Coccomyxa Schmidle. New Phytol. 77: 713-718.

Reichle, R. E. and Alexander, J. V. (1965) Multiperforate septations, Woronin bodies, and septal plugs in Fusarium. F. Cell Biol. 24: 489-496.

Ried, A. (1960a) Stoffwechsel und Verbreitungsgrenzen von Flechten. II. Wasser und Assimilationshaushalt, Entquellungs- und Submersionsresistenz von Krustenflechten benachbarter Standorte. Flora, Fena 149: 345-385.

Ried, A. (1960b) Thallusbau und Assimilationshaushalt von Laub- und Krustenflechten. Biol. Zbl. 79: 129-151.

Richardson, D. H. S. (1973) Photosynthesis and carbohydrate movement. In The Lichens (V. Ahmadjian and M. E. Hale, eds): 249-288. New York and London: Academic Press.

Richardson, D. H. S., Smith, D. C. and Lewis, D. H. (1967) Carbohydrate movement between the symbionts of lichens. Nature, Lond. 214: 879-882.

Rudolph, E. D. and Giesy, R. M. (1966) Electron microscope studies of lichen reproductive structures in Physica aipolia. Mycologia 58: 786-796.

Scott, G. D. (1964) The lichen symbiosis. Advmt Sci., Lond. 31: 244-248.

Webber, M. M. and Webber, P. J. (1970) Ultrastructure of lichen haustoria: symbiosis in Parmelia sulcata. Can. F. Bot. 48: 1521-1524.

Accepted for publication 12 fanuary 1978 